\title{
Cold-hardiness and Deacclimation of Styrax americanus from Three Provenances
}

\author{
Olivia M. Lenahan, William R. Graves ${ }^{1}$, and Rajeev Arora \\ Department of Horticulture, Iowa State University, Ames, IA 50011
}

Additional index words. American snowbell, LT50, native plants, Styracaceae, nursery crops

\begin{abstract}
Styrax americanus Lam. (American snowbell) is a deciduous shrub or small tree seldom produced in nurseries. This species is distributed in patchy populations found mainly from Florida to southern Illinois, although a small, disjunct population exists in northern Illinois. The winter-hardiness and loss of hardiness during a period of increased temperature (deacclimation) of plants from this disjunct population may differ from those of $S$. americanus elsewhere. We examined cold-hardiness and deacclimation of stems of plants from the disjunct population, from southern Illinois, and from Florida. Segments of stems removed from plants grown outdoors in Ames, IA, were exposed to low-temperature ramping, and the temperature at which stems showed $50 \%$ damage $\left(\mathbf{L T}_{\mathbf{5 0}}\right)$ was determined by using the tissue-discoloration method. To assess deacclimation, stem segments were collected from cold-acclimated plants during winter in a minimally heated greenhouse and exposed to controlled warm temperatures for various time intervals followed by low-temperature ramping. Plants from Illinois were $\approx 15^{\circ} \mathrm{C}$ more cold-hardy than plants from Florida in Feb. 2008. Plants from the disjunct population in northern Illinois showed less stem tip injury than did plants from southern Illinois. Deacclimation patterns were similar between plants from both Illinois populations. Plants sampled in Apr. 2009 from Florida deacclimated more rapidly than corresponding samples from Illinois, and the chilling required to overcome endodormancy increased with increasing latitude of plant origin. This research suggests that germplasm from the Illinois populations should be used in regions where the poorer hardiness and deacclimation resistance of most $S$. americanus would not permit survival.
\end{abstract}

The Styrax L. genus contains $\approx 130$ species distributed in Asia, the Mediterranean, South America, and North America (Fritsch, 1999). Two species from Asia, Styrax japonicus Sieb. \& Zucc. (Japanese snowbell) and Styrax obassia Sieb. \& Zucc. (fragrant snowbell), are the most frequently planted members of the genus in landscapes in the United States. Styrax americanus Lam. (American snowbell) is rarely cultivated (Dirr, 1978) but forms attractive shrubs or small trees up to $4 \mathrm{~m}$ tall that occur in nature at moist sites alongside streams, near swamp margins, and in floodplains (Gonsoulin, 1974). The species blooms in late spring, producing dainty inflorescences of white fragrant flowers with reflexed petals. In fall, hard drupes adorn the branches, and striped bark adds ornamental interest.

\footnotetext{
Received for publication 21 June 2010. Accepted for publication 11 Oct. 2010.

Journal paper of the Iowa Agriculture and Home Economics Experiment Station, Ames, IA, and supported by the Hatch Act and State of Iowa funds.

We acknowledge technical assistance from Ed Moran, James Schrader, Arlen Patrick, and Peter Lawlor. Allan Trapp provided helpful guidance with statistical procedures.

${ }^{1}$ To whom reprint requests should be addressed; e-mail graves@iastate.edu.
}

Styrax americanus occurs throughout much of the southeastern United States and is distributed continuously as far north as southeastern Virginia and southern Illinois. We are particularly interested in the northern limit of the distribution, which is a disjunct population located in the Momence Wetlands of northern Illinois, $\approx 500 \mathrm{~km}$ north of the closest populations to the south (Phillippe et al., 2003). Numerous factors, including its resistance to environmental stressors, must be examined before the potential for $S$. americanus as a species for the nursery and landscape industries is understood. Low temperatures restrict where many woody species can be used, and little is known about the cold tolerance of $S$. americanus. Therefore, we investigated midwinter-hardiness and deacclimation patterns of populations of $S$. americanus from northern and southern locations within its natural distribution.

Cold acclimation is the accrual of coldhardiness in response to lengthening nights and declining temperatures. Deacclimation is the loss of cold-hardiness in response to environmental and phenological changes (Kalberer et al., 2006). Increasing temperatures, rather than lengthening photoperiods, principally govern the deacclimation process (Beck et al., 2004). The capacity of a woody species to resist deacclimation when exposed to unseasonably warm temperatures in late winter and early spring is an important trait to consider when specifying taxa for placement in horticultural landscapes (Taulavuori et al., 2004; Wolf and Cook, 1992). Our objectives were to determine if plants from the northernmost disjunct population of $S$. americanus are more cold-tolerant than plants from other populations and to compare plants from different provenances for their resistance to deacclimation and their chilling requirement. Our results provide needed information about variation in tolerance to low temperature among provenances of this North American species.

\section{Materials and Methods}

Plant material. Styrax americanus were grown singly in plastic pots $(18 \mathrm{~cm}$ tall, $16.5 \mathrm{~cm}$ wide, $3.8 \mathrm{~L}$ ) in a mixture of $50 \%$ processed pine bark, 35\% sphagnum peat, and $15 \%$ perlite (by volume) (Fafard ${ }^{\circledR} 51$; Fafard, Inc., Agawam, MA). Plants were from three sources in the wild (Table 1). Both rooted stem cuttings and plants grown from seed represented the northern, disjunct population in Illinois (lat. $41^{\circ} 9^{\prime} \mathrm{N}$; long. $\left.87^{\circ} 33^{\prime} \mathrm{W}\right)$. Seedlings from a wetland in southern Illinois (lat. 37 $22^{\prime} 20^{\prime \prime} \mathrm{N}$; long. $\left.88^{\circ} 40^{\prime} 44^{\prime \prime} \mathrm{W}\right)$ and seedlings grown by Superior Tree Nursery (Lee, FL) from seeds collected near Lee, FL (lat. $30^{\circ} 41^{\prime} \mathrm{N}$; long. $83^{\circ} 30^{\prime} \mathrm{W}$ ), were used. All plants were 2 years old and sexually mature when their midwinter-hardiness was assessed during the winter of 2007-2008. Tissues for midwinterhardiness determinations were taken from a field plot established on the campus of Iowa State University in Ames, IA (USDA coldhardiness zone 5a) (lat. $42^{\circ} 06^{\prime} \mathrm{N}$; long. $93^{\circ} 65^{\prime} \mathrm{W}$ ) in 2007 . The plot was composed of 30 plants, 10 from each provenance, arranged in a completely random design. Plants were spaced $1 \mathrm{~m}$ apart and were irrigated with tap water weekly. Organic mulch was used on the plot to minimize weed pressure. Air temperature was recorded by two i-buttons (Maxim Integrated Products, Sunnyvale, CA) attached to the shoot of two plants $\approx 66 \mathrm{~cm}$ above the ground. Tissue for deacclimation experiments came from plants arranged in a completely random design in a greenhouse in Ames, IA. There were 113 seedlings total, 18 from the habitat in northern Illinois, 40 from southern Illinois, and 55 from Florida. Plants were exposed to natural photoperiod. The greenhouse was vented but not otherwise cooled and was minimally heated to prevent temperatures less than $2{ }^{\circ} \mathrm{C}$ during winter. Mean air temperatures, logged with i-buttons located $\approx 35 \mathrm{~cm}$ above the greenhouse bench, for Jan. and Mar. 2008 were 5.8 and $10.5^{\circ} \mathrm{C}$, respectively; means in Jan., Feb., Mar., and Apr. 2009 were $7.5,10.7,10.5$, and $14.8^{\circ} \mathrm{C}$, respectively.

Deacclimation treatment and seasonal field cold-hardiness sampling. Deacclimation trials took place in Jan. and Mar. 2008 and from Jan. to Apr. 2009. Stems formed in the previous year were randomly chosen from all plants in the greenhouse. Shoots $\approx 8 \mathrm{~cm}$ in length were collected, after which the terminal $4 \mathrm{~cm}$ of the shoot was removed. Stems 
were placed singly in 16 -mm-diameter test tubes with $\approx 2 \mathrm{~mL}$ deionized water and were exposed to $22{ }^{\circ} \mathrm{C}$ day $/ 15{ }^{\circ} \mathrm{C}$ night and $14-\mathrm{h}$ photoperiods (i.e., deacclimating conditions). For the cold-hardiness determination of progressively deacclimating shoots, samples were subjected to a freeze-thaw regime on Days 0 (cold-acclimated stem tissue), 2, 6, and 15 of deacclimation treatment. To assess seasonal field cold-hardiness, stem tissues formed in the previous year were collected monthly from all plants in the field plot from Oct. 2007 to Mar. 2008 and from Aug. to Dec. 2008. Data from both years were combined to form one seasonal hardiness curve.

Freeze-thaw protocol and cold-hardiness determination. Stem sections subjected to a controlled freeze-thaw regime were $\approx 4 \mathrm{~cm}$ in length after the terminal 4-cm section was removed. Each test for deacclimation and field hardiness was performed in a programmable freezer (Scientemp, Adrian, MI) and consisted of a control $\left(4^{\circ} \mathrm{C}\right)$ and seven lower temperatures. Temperature ranges used in the deacclimation study (Table 2) varied each month and within each deacclimation treatment and represented the estimated range of $0 \%$ to $100 \%$ tissue injury. Five stem replica-

Table 1. Latitude, USDA cold-hardiness zone, and historical minima of locations where seeds and stem cuttings of Styrax americanus were obtained.

\begin{tabular}{lccc}
\hline & & USDA cold-hardiness & \\
Population & Latitude & zone & Historical minima $\left({ }^{\circ} \mathrm{C}\right)^{z}$ \\
\hline Northern Illinois & $41^{\circ} 10^{\prime} \mathrm{N}$ & $5 \mathrm{a}$ & $-34(1985)$ \\
Southern Illinois & $37^{\circ} 22^{\prime} \mathrm{N}$ & $6 \mathrm{a}$ & $-29(1977)$ \\
Florida & $30^{\circ} 42^{\prime} \mathrm{N}$ & $9 \mathrm{a}$ & $-15(1985)$ \\
\hline
\end{tabular}

${ }^{\mathrm{z}}$ Minima obtained from the weather station closest to each population. Data are from January, the coldest month in each location, over an $\approx 75$-year period (http://www.weather.com; The Weather Channel, 2009). Dates after the historical minima indicate when the record occurred during that $\approx 75$-year period.

Table 2. Ranges of the treatment temperatures used in the laboratory freeze-thaw test during deacclimation studies of stem tissue of Styrax americanus. ${ }^{z}$

\begin{tabular}{|c|c|c|}
\hline \multirow[b]{2}{*}{ Treatment } & \multicolumn{2}{|c|}{ Range of treatment temp. } \\
\hline & 2008 & 2009 \\
\hline \multicolumn{3}{|l|}{$\overline{\text { January }}$} \\
\hline Day 0 & -28 to $-52{ }^{\circ} \mathrm{C} ;-18$ to $-42{ }^{\circ} \mathrm{C}$ & -26 to $-50{ }^{\circ} \mathrm{C} ;-16$ to $-40^{\circ} \mathrm{C}$ \\
\hline Day 2 & -22 to $-46^{\circ} \mathrm{C} ;-18$ to $-42^{\circ} \mathrm{C}$ & -26 to $-50{ }^{\circ} \mathrm{C} ;-16$ to $-40^{\circ} \mathrm{C}$ \\
\hline Day 6 & -22 to $-46{ }^{\circ} \mathrm{C} ;-14$ to $-38{ }^{\circ} \mathrm{C}$ & -22 to $-46{ }^{\circ} \mathrm{C} ;-14$ to $-38{ }^{\circ} \mathrm{C}$ \\
\hline Day 15 & -18 to $-42{ }^{\circ} \mathrm{C} ;-10$ to $-34{ }^{\circ} \mathrm{C}$ & -14 to $-38^{\circ} \mathrm{C}$ \\
\hline \multicolumn{3}{|l|}{ February } \\
\hline Day 0 & NT & -26 to $-50{ }^{\circ} \mathrm{C} ;-16$ to $-40{ }^{\circ} \mathrm{C}$ \\
\hline Day 2 & NT & -26 to $-50{ }^{\circ} \mathrm{C} ;-16$ to $-40^{\circ} \mathrm{C}$ \\
\hline Day 6 & NT & -22 to $-46{ }^{\circ} \mathrm{C} ;-14$ to $-38^{\circ} \mathrm{C}$ \\
\hline Day 15 & NT & -14 to $-38^{\circ} \mathrm{C} ;-12$ to $-36{ }^{\circ} \mathrm{C}$ \\
\hline \multicolumn{3}{|l|}{ March } \\
\hline Day 0 & -20 to $-44{ }^{\circ} \mathrm{C} ;-16$ to $-40{ }^{\circ} \mathrm{C}$ & -16 to $-40{ }^{\circ} \mathrm{C} ;-12$ to $-36{ }^{\circ} \mathrm{C}$ \\
\hline Day 2 & -20 to $-44{ }^{\circ} \mathrm{C} ;-16$ to $-40{ }^{\circ} \mathrm{C}$ & -16 to $-40{ }^{\circ} \mathrm{C} ;-12$ to $-36{ }^{\circ} \mathrm{C}$ \\
\hline Day 6 & -20 to $-44^{\circ} \mathrm{C} ;-14$ to $-36^{\circ} \mathrm{C}$ & -12 to $-36^{\circ} \mathrm{C}$ \\
\hline Day 15 & -14 to $-36^{\circ} \mathrm{C}$ & -6 to $-30{ }^{\circ} \mathrm{C}$ \\
\hline \multicolumn{3}{|l|}{ April } \\
\hline Day 0 & NT & -2 to $-26^{\circ} \mathrm{C}$ \\
\hline Day 2 & NT & -2 to $-26{ }^{\circ} \mathrm{C}$ \\
\hline Day 6 & NT & -2 to $-26{ }^{\circ} \mathrm{C}$ \\
\hline Day 15 & NT & -2 to $-26{ }^{\circ} \mathrm{C}$ \\
\hline
\end{tabular}

${ }^{\mathrm{z}}$ The first range of temperatures for each treatment was applied to both populations from Illinois; the second range was applied to the population from Florida.

$\mathrm{NT}=$ no test during that month. for $3 \mathrm{~h}$. Ice crystals were added to each test tube to promote ice nucleation. Next, samples were held at $-3{ }^{\circ} \mathrm{C}$ and then $-4{ }^{\circ} \mathrm{C}$ for $1 \mathrm{~h}$ each. Freezer temperature then was decreased $-2{ }^{\circ} \mathrm{C} \cdot \mathrm{h}^{-1}$. Subsequently, samples were removed at $-4{ }^{\circ} \mathrm{C}$ increments to a minimum lethal temperature (Table 2) based on the temperature of the stem tissue, placed on ice for $4 \mathrm{~h}$, and held at $4{ }^{\circ} \mathrm{C}$ for $\approx 15 \mathrm{~h}$. Test tubes were covered with parafilm ${ }^{\circledR}$ (SPI Supplies, West Chester, PA) and held in darkness at room temperature $\left(22^{\circ} \mathrm{C}\right)$ for $11 \mathrm{~d}$ before stem samples were evaluated for injury.

Cold-hardiness was determined based on visual symptoms of freeze-thaw injury. Cambial stem tissue of each sample was viewed longitudinally and by cross-section with a dissecting microscope. Each section was rated on an injury scale from 1 to $4(1=$ green tissue, 2 = green/yellow tissue, 3 = light colored brown/yellow tissue, and $4=$ brown tissue) (Harrison et al., 1978; Zimmerman et al., 2005), and the two ratings for each stem replicate were averaged. Based on methods used by Arora et al. (2004) and Rowland et al. (2005), the five mean injury values at each of the seven temperatures for each population were bootstrapped (Manly, 1997) 3000 times using the R-program (R Development Core Team, 2009). A sigmoidal curve was fit to injury scores versus temperature for each of the 3000 sets of bootstrapped data and interpolated at $50 \%$ injury to give $\mathrm{LT}_{50}$ temperatures (Ehlenfeldt et al., 2006). Stemregrowth tests confirmed that $50 \%$ tissue injury corresponded with the lowest temperature at which there was budbreak. Differences among means were determined by non-overlapping $90 \%$ confidence intervals.

Chilling requirement determination. Chilling requirement of plants from each of three populations was estimated from stem segments collected from plants in the greenhouse at 10 - to $12-\mathrm{d}$ intervals from 11 Oct. 2008 to 12 Mar. 2009. At each collection, three stem segments that were $\approx 6 \mathrm{~cm}$ long and had at least three nodes were collected from four plants per population. Each segment was placed in an individual test tube $(16 \mathrm{~mm}$ diameter) that contained $\approx 2 \mathrm{~mL}$ of a sugar solution as described by Kalberer et al. (2007a). Tubes were placed in a growth chamber at $25^{\circ} \mathrm{C}$, provided constant irradiance, and were randomized within test tube racks that were moved to different positions within the growth chamber every $2 \mathrm{~d}$. The stem samples were placed in fresh solution in a clean tube every 2 to $3 \mathrm{~d}$ after removing $\approx 5 \mathrm{~mm}$ from the submerged end of the sample.

To determine chilling requirement, daily observations were made of budbreak (i.e., appearance of a leaf), and the percentage of total buds broken on each stem sample was recorded. Air temperature in the greenhouse was logged with i-buttons every $90 \mathrm{~min}$ from 1 Oct. 2008 to 15 Mar. 2009. One chill unit was assigned to each hour at which the temperature was below $7.2{ }^{\circ} \mathrm{C}$ (Powell et al., 1999). Percentage budbreak was plotted over chilling hours for each population and fit to a sigmoidal survival curve, and chilling 
requirement was determined as the chilling needed to evoke 50\% budbreak (Kalberer et al., 2007a).

\section{Results}

Seasonal field cold-hardiness. Plants from both Illinois populations increased coldhardiness from $-19{ }^{\circ} \mathrm{C}$ in August to $-48{ }^{\circ} \mathrm{C}$ in February. Plants from Florida increased coldhardiness from $-12{ }^{\circ} \mathrm{C}$ in August to $-34{ }^{\circ} \mathrm{C}$ in February and consistently were less coldhardy than were plants from Illinois (Fig. 1). There was no gain in cold-hardiness of plants from any population from August to September. Hardiness of plants from Florida did not increase until December (Fig. 1). Plants from northern and southern Illinois exhibited similar cold-hardiness in all months except Janu- ary, when individuals from northern Illinois were $3{ }^{\circ} \mathrm{C}$ more hardy than plants from southern Illinois. Plants from all populations showed greater midwinter-hardiness than 75-year record low temperatures from each site (Fig. 1; Table 1).

Deacclimation and chilling requirement. During 2008, plants from northern and southern Illinois exhibited statistically equivalent $\mathrm{LT}_{50}$ values after all deacclimation treatments in January and March, whereas plants from Florida were less cold-hardy on all measurement days compared with plants from Illinois (Table 3). After $15 \mathrm{~d}$ of warm treatment, plants from northern and southern Illinois lost 10.7 and $9.6{ }^{\circ} \mathrm{C}$ of cold-hardiness in January, respectively, and 15.5 and $18.1{ }^{\circ} \mathrm{C}$ of cold-hardiness in March, respectively. Plants from Florida lost $8.9^{\circ} \mathrm{C}$ of hardiness

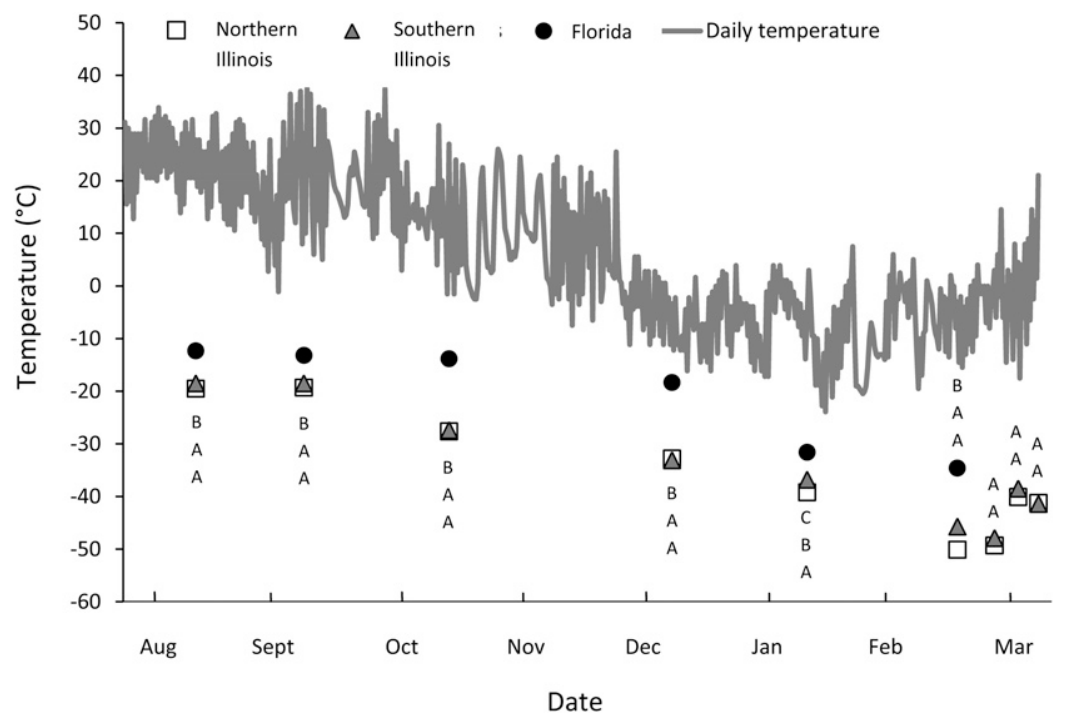

Fig. 1. $\mathrm{LT}_{50}$ values $\left({ }^{\circ} \mathrm{C}\right)$ of stem tissue of Styrax americanus from three populations measured Oct. 2007 to Mar. 2008 and August to Dec. 2008. Data from 2007 and 2008 were combined to form one seasonal hardiness curve. Stem samples were collected from plants grown outdoors in Ames, IA, and tissue injury was determined by laboratory freezing tests. Temperature was measured at the field plot by ibutton sensors (Maxim Integrated Products, Sunnyvale, CA). The order of letters from top to bottom at each measurement day represents plants from Florida, southern Illinois, and northern Illinois. As a result of limited stem material of plants from Florida, measurements on the last three dates only represent plants from southern Illinois and northern Illinois. $\mathrm{LT}_{50}$ values with the same letter are not different according to $90 \%$ confidence intervals.

Table 3. Cold-hardiness of stem tissue $\left(\mathrm{LT}_{50}\right)$ of three populations of Styrax americanus measured after 2,6 , and $15 \mathrm{~d}$ of deacclimating conditions $\left(22^{\circ} \mathrm{C}\right.$ day $/ 15^{\circ} \mathrm{C}$ night; 14 -h photoperiods $)$ in $2008 .{ }^{2}$

\begin{tabular}{lcccc}
\hline 2008 Month and population & $0^{\mathrm{y}}$ & 2 & 6 & 15 \\
\hline January & & & & \\
$\quad$ Northern Illinois & $-39.5 \mathrm{a}^{\mathrm{x}}$ & $-37.9 \mathrm{a}$ & $-34.6 \mathrm{a}$ & $-28.8 \mathrm{a}$ \\
$\quad$ Southern Illinois & $-38.9 \mathrm{a}$ & $-36.5 \mathrm{a}$ & $-34.7 \mathrm{a}$ & $-29.3 \mathrm{a}$ \\
Florida & $-31.9 \mathrm{~b}$ & $-31.9 \mathrm{~b}$ & $-26.3 \mathrm{~b}$ & $-23.0 \mathrm{~b}$ \\
& & & & \\
March & & & & $-19.2 \mathrm{a}$ \\
$\quad$ Northern Illinois & $-34.7 \mathrm{a}$ & $-34.5 \mathrm{a}$ & $-25.7 \mathrm{a}$ & $-17.3 \mathrm{a}$ \\
$\quad$ Southern Illinois & $-35.4 \mathrm{a}$ & $-33.5 \mathrm{a}$ & $-25.1 \mathrm{a}$ & $-{ }^{\mathrm{w}}$ \\
$\quad$ Florida & $-28.8 \mathrm{~b}$ & $-25.1 \mathrm{~b}$ & $-17.5 \mathrm{~b}$ & $\mathrm{w}$
\end{tabular}

${ }^{\text {}}$ Plants were from northern Illinois, southern Illinois, and Florida. Deacclimation trials took place in January and March.

${ }^{\mathrm{y}} \mathrm{LT}_{50}$ values on Day 0 represent cold-acclimated stem tissue collected from a minimally heated greenhouse in Ames, IA.

${ }^{\times} \mathrm{LT}_{50}$ values within each column and month followed by a different letter are different according to $90 \%$ confidence intervals.

${ }^{\mathrm{w}} \mathrm{LT}_{50}$ value could not be determined with the temperature range used on Day 15. after $15 \mathrm{~d}$ of warm treatment in January. Loss of hardiness in March could not be determined based on the temperature treatment range in that month (Table 2). Plants from Florida sampled in January showed no loss of cold-hardiness within the first $2 \mathrm{~d}$ of deacclimation, whereas March samples lost $3.7^{\circ} \mathrm{C}$ hardiness $\left(1.9^{\circ} \mathrm{C} \cdot \mathrm{d}^{-1}\right)$ within the first $2 \mathrm{~d}$ of warm treatment.

In 2009, plants from all populations lost an average $18{ }^{\circ} \mathrm{C}$ of cold-hardiness from January to April in the greenhouse before any deacclimation treatment (Table 4). Plants from northern and southern Illinois exhibited similar $\mathrm{LT}_{50}$ values on all days and in all months with one exception. Results suggest that plants from northern Illinois were $2{ }^{\circ} \mathrm{C}$ hardier than plants from southern Illinois after $2 \mathrm{~d}$ of deacclimation in January. Similar to results in 2008, cold-hardiness of stem tissue from Florida was consistently lower than that from both Illinois populations on all days and in all months (Tables 3 and 4). Among all populations, plants from Florida exhibited the greatest loss of cold-hardiness in April $\left(3.3{ }^{\circ} \mathrm{C} \cdot \mathrm{d}^{-1}\right)$ after $2 \mathrm{~d}$ in warmth (Table 4). Moreover, in February, plants from Florida exhibited a rate loss of hardiness between Days 6 and $15\left(1.0{ }^{\circ} \mathrm{C} \cdot \mathrm{d}^{-1}\right)$ that was five- and threefold greater than that for plants from northern and southern Illinois, respectively. Plants from Florida had the lowest chilling requirement to overcome endodormancy, showing 50\% budbreak at 351 chilling units. Plants from southern and northern Illinois showed $50 \%$ budbreak at 481 and 520 chill units, respectively.

\section{Discussion}

The cold-hardiness of plants from northern Illinois and southern Illinois was similar on most days in winter and greater than that of plants from Florida (Fig. 1). Our results are similar to those of other studies of North American woody species from disparate provenances that have shown a positive association between winter-hardiness and latitude of seed source (Graves et al., 2006; Sharma and Graves, 2004). The seasonal pattern of cold-hardiness of all populations indicates that this species can survive winters colder than would be expected based on their native habitat. For example, the historical minima recorded near the northern and southern Illinois and Florida locations are $-34,-29$, and $-15{ }^{\circ} \mathrm{C}$, respectively (Table 1 ). Our results suggest that plants from Florida could survive temperatures as low as $-34^{\circ} \mathrm{C}$, whereas those from northern and southern Illinois could tolerate $-48{ }^{\circ} \mathrm{C}$.

It is important to note that our data are based only on stem hardiness, whereas the cold-hardiness of roots, flower buds, and chronological age-dependent changes (Lim et al., 1999) in cold-hardiness of our plantings are also important factors for winter survival of $S$. americanus. Other woody species, including Alnus maritima (Marsh.) Muhl ex Nutt., Quercus rubra L., and Salix spp., also reportedly possessed greater cold tolerance 
Table 4. Cold-hardiness of stem tissue $\left(\mathrm{LT}_{50}\right)$ of three populations of Styrax americanus measured after 2,6 , and $15 \mathrm{~d}$ of deacclimating conditions $\left(22^{\circ} \mathrm{C}\right.$ day/ $15{ }^{\circ} \mathrm{C}$ night; 14 -hr photoperiods) in 2009.

\begin{tabular}{|c|c|c|c|c|}
\hline 2009 Month and population & $0^{\mathrm{z}}$ & 2 & 6 & 15 \\
\hline \multicolumn{5}{|l|}{ January } \\
\hline Northern Illinois & $-37.7 a^{y}$ & $-37.2 \mathrm{a}$ & $-30.2 \mathrm{a}$ & $-30.0 \mathrm{a}$ \\
\hline Southern Illinois & $-38.3 \mathrm{a}$ & $-35.3 \mathrm{~b}$ & $-29.4 \mathrm{a}$ & $-29.0 \mathrm{a}$ \\
\hline Florida & $-26.3 \mathrm{~b}$ & $-28.1 \mathrm{c}$ & $-22.4 \mathrm{~b}$ & $-25.0 \mathrm{~b}$ \\
\hline \multicolumn{5}{|l|}{ February } \\
\hline Northern Illinois & $-36.4 \mathrm{a}$ & $-34.2 \mathrm{a}$ & $-29.1 \mathrm{a}$ & $-27.1 \mathrm{a}$ \\
\hline Southern Illinois & $-35.6 \mathrm{a}$ & $-33.8 \mathrm{a}$ & $-28.7 \mathrm{a}$ & $-26.0 \mathrm{a}$ \\
\hline Florida & $-28.4 \mathrm{~b}$ & $-27.6 \mathrm{~b}$ & $-23.8 \mathrm{~b}$ & $-15.1 \mathrm{~b}$ \\
\hline \multicolumn{5}{|l|}{ March } \\
\hline Northern Illinois & $-25.4 \mathrm{a}$ & $-25.6 \mathrm{a}$ & $-21.1 \mathrm{a}$ & $-15.5 \mathrm{a}$ \\
\hline Southern Illinois & $-26.5 \mathrm{a}$ & $-24.6 \mathrm{a}$ & $-19.1 \mathrm{a}$ & $-13.9 \mathrm{a}$ \\
\hline Florida & $-20.6 b$ & $-18.2 b$ & $-14.9 b$ & $-11.2 b$ \\
\hline \multicolumn{5}{|l|}{ April } \\
\hline Northern Illinois & $-17.8 \mathrm{a}$ & $-16.7 \mathrm{a}$ & $-13.6 \mathrm{a}$ & $-11.9 \mathrm{a}$ \\
\hline Southern Illinois & $-17.4 \mathrm{a}$ & $-17.8 \mathrm{a}$ & $-13.2 \mathrm{a}$ & $-11.7 \mathrm{a}$ \\
\hline Florida & $-13.8 \mathrm{~b}$ & $-7.2 \mathrm{~b}$ & $-6.3 b$ & $-6.3 b$ \\
\hline
\end{tabular}

${ }^{\mathrm{z}} \mathrm{LT}_{50}$ values on Day 0 represent cold-acclimated stem tissue collected from a minimally heated greenhouse in Ames, IA.

${ }^{\mathrm{y}} \mathrm{LT}_{50}$ values within each column and month followed by a different letter are different according to $90 \%$ confidence intervals.

than was necessary for survival in the climates where the tested germplasm was collected (Flint, 1972; Lennartsson and Ogren, 2002; Schrader and Graves, 2003). For example, Schrader and Graves (2003) reported that subspecies of $A$. maritima originating from Oklahoma and Georgia (cold-hardiness zone 7) were cold-hardy to -61 and $-66{ }^{\circ} \mathrm{C}$, respectively. The $\mathrm{LT}_{50}$ values we report here estimate the lowest temperature at which $S$. americanus stem tissues could survive. Although stem tissues showed a capacity to survive colder temperatures than would be expected based on the native habitat, we observed death of tips of stems in $71 \%, 36 \%$, and $10 \%$ of plants from Florida, southern Illinois, and northern Illinois, respectively, averaged over two seasons. Extensive death of stem tips of plants from Florida may be the result of a slow rate of cold acclimation leading to vulnerability to early frosts. For example, tissue injury in this population could have occurred in December when the minimum temperatures were close to the estimated $\mathrm{LT}_{50}$ (Fig. 1). Others also have reported slower cold acclimation rates of North American taxa in southern populations compared with plants from northern sites (Donselman and Flint, 1982; Karlson et al., 2003).

The loss of cold tolerance in S. americanus after $15 \mathrm{~d}$ of deacclimating conditions is similar to results of other deacclimation studies. For example, floral buds of southern and northern blueberry cultivars (Vaccinium L.) lost 15 and $20{ }^{\circ} \mathrm{C}$ cold-hardiness, respectively, after $16 \mathrm{~d}$ of warmth in February (Arora et al., 2004). Our results with $S$. americanus in Feb. 2009 show a similar loss of $13{ }^{\circ} \mathrm{C}$ of cold-hardiness of stem tissue from Florida and a $10{ }^{\circ} \mathrm{C}$ loss in the populations from Illinois after $15 \mathrm{~d}$. It is unclear why samples from Florida collected in January showed fluctuating increases of hardiness (Table 4).
Our results suggest that the capacity of $S$. americanus to resist deacclimation varies among the northern and southern populations. For example, plants from Florida showed high deacclimation resistance within the first $2 \mathrm{~d}$ of treatment in January 2008 (Table 3). This result is consistent with deacclimation studies on azalea (Rhododendron L.) and blueberry that showed a lack of association between high deacclimation resistance and high midwinter-hardiness (Arora et al., 2004; Kalberer et al., 2007b). As the season progressed in 2009, plants from Florida exhibited a deacclimation rate of $3.3{ }^{\circ} \mathrm{C} \cdot \mathrm{d}^{-1}$ within the first $2 \mathrm{~d}$ of April, whereas plants from northern Illinois exhibited a deacclimation rate of $0.5{ }^{\circ} \mathrm{C} \cdot \mathrm{d}^{-1}$ (Table 4). A similar result was found in cultivars of blueberry, in which plants from southern provenances had faster rates of deacclimation during the first $3 \mathrm{~d}$ of warm temperatures compared with plants from northern provenances (Arora et al., 2004). Plants from northern and southern Illinois exhibited similar cold-hardiness after most warm treatments. Although samples collected in January from northern Illinois in 2009 exhibited greater cold-hardiness after $2 \mathrm{~d}$ of warmth than did samples from southern Illinois, overall, the data suggest that plants from the Illinois provenances have similar cold-hardiness after episodes of warmth.

The stage of active growth and depth of dormancy may influence the rate of deacclimation in S. americanus. Our results show that chilling requirement increased with increasing latitude of plant origin from Florida to northern Illinois. A trend of increasing chilling requirement with latitude has also been reported in Cercis canadensis L. (Donselman and Flint, 1982) and Ulmus spp. (Ghelardini and Santini, 2009). However, others have reported an opposite trend, in which chilling requirement decreased from south to north (Kalberer et al., 2007b; Taulavuori et al., 2004). Kalberer et al. (2007b) explained the higher chilling requirement of azaleas from southern populations is advantageous for delaying budbreak until after episodes of frost in a comparatively variable climate, whereas the need to prevent early budbreak is less important in a northern coastal population where temperatures are not as variable.

Data on deacclimation in woody species have been used to predict landscape survival in different climates. For example, Murray and Byrnes (1975) showed that stem tissue of Juglans nigra L. (black walnut) was highly resistant to deacclimation after exposure to warm nights; stem tissue showed injury at $-18{ }^{\circ} \mathrm{C}$ after $8 \mathrm{~d}$. This level of cold tolerance was greater than low temperatures recorded near the area of interest and led to the recommendation for further plantings. The deacclimation results in $S$. americanus are promising in that plants from Illinois, after exposure to warm temperatures for $15 \mathrm{~d}$, retained enough hardiness in January and February to survive temperatures in coldhardiness zones $5 \mathrm{a}$ and $5 \mathrm{~b}$, respectively (U.S. National Arboretum, 2003) (Tables 3 and 4). Moreover, results suggest that plants from Florida, after the same treatment, could survive in zones $6 \mathrm{a}$ and $7 \mathrm{a}$ in January and February, respectively. It is important to point out that plants in the deacclimation study were kept in a chilled greenhouse and thus were less cold-hardy than plants subjected to subzero temperatures in the field. Studies of deacclimating plants in the field may show different levels of cold-hardiness after episodes of warmth as a result of greater starting coldhardiness levels as well as diurnal temperature fluctuations such as a drop in night temperatures of less than $0{ }^{\circ} \mathrm{C}$ and a rise in day temperatures of greater than $0{ }^{\circ} \mathrm{C}$.

The results of this study indicate that $S$. americanus from Illinois can survive harsher winters than necessary to persist in their native habitat. Freezing test results and observations of stem dieback indicate that germplasm from the northern population might be useful in USDA hardiness zone 4, and germplasm from southern Illinois may function in protected niches within zone 5 . The resistance to deacclimation exhibited by these two populations in April also supports their potential value as landscape plants in regions that experience late spring frosts. Plants from Florida should not be installed in horticultural landscapes where winters are harsher than those in USDA cold-hardiness zone 7 as a result of the increased chance of frost damage in fall and the speed of deacclimation in late spring. Further field studies should be conducted to evaluate whole-plant survival and the hardiness of floral buds in nursery and landscape settings in northern regions of the country.

\section{Literature Cited}

Arora, R., L.J. Rowland, E.L. Ogen, A.L. Dhanaraj, C.O. Marian, M.K. Ehlenfeldt, and B. Vinyard. 2004. Dehardening kinetics, bud development, and dehydrin metabolism in blueberry cultivars 
during deacclimation at constant, warm temperatures. J. Amer. Soc. Hort. Sci. 129:667-674.

Beck, E.H., R. Heim, and J. Hansen. 2004. Plant resistance to cold stress: Mechanisms and environmental signals triggering frost hardening and dehardening. J. Biosci. 29:449-459.

Dirr, M.A. 1978. The exquisite snowbells. Amer. Nurseryman 147:7-8, 87-90.

Donselman, H.M. and H.L. Flint. 1982. Genecology of eastern redbud (Cercis canadensis). Ecology 63:962-971.

Ehlenfeldt, M.K., E.L. Ogden, and L.J. Rowland. 2006. Evaluation of midwinter cold hardiness among 25 rabbiteye blueberry cultivars. HortScience 41:579-581.

Flint, H.L. 1972. Cold hardiness of twigs of Quercus rubra L. as a function of geographic origin. Ecology 53:1163-1170.

Fritsch, P.W. 1999. Phylogeny of Styrax based on morphological characters, with implications for biogeography and infrageneric classification. Syst. Bot. 24:356-378.

Ghelardini, L. and A. Santini. 2009. Avoidance by early flushing: A new perspective on Dutch elm disease research. iForest 2:143-153.

Gonsoulin, G.J. 1974. A revision of Styrax (Styracaceae) in North America, Central America, and the Caribbean. Sida 5:191-258.

Graves, W.R., J.A. Schrader, and J. Sharma. 2006. Cold hardiness of the rare Dirca occidentalis: Comparisons to Dirca palustris from disparate provenances. J. Environ. Hort. 24:169-172.

Harrison, L.C., C.J. Weiser, and M.J. Burke. 1978. Freezing of water in red-osier dogwood stems in relation to cold hardiness. Plant Physiol. 62: 899-901.

Kalberer, S., R. Arora, N. Leyva-Estrada, and S.L. Krebs. 2007a. Cold hardiness of floral buds of deciduous azaleas: Dehardening, rehardening, and endodormancy in late winter. J. Amer. Soc. Hort. Sci. 132:73-79.

Kalberer, S.R., N. Leyva-Estrada, S.L. Krebs, and R. Arora. 2007b. Frost dehardening and rehardening of floral buds of deciduous azaleas are influenced by genotypic biogeography. Environ. Exp. Bot. 59:264-275.

Kalberer, S.R., M. Wisniewski, and R. Arora. 2006. Deacclimation and reacclimation of cold-hardy plants: Current understanding and emerging concepts. Plant Sci. 171:3-16.

Karlson, D.T., Y. Zeng, V.E. Stirm, R.J. Joly, and E.N. Ashworth. 2003. Photoperiodic regulation of a $24-\mathrm{kD}$ dehydrin-like protein in redosier dogwood (Cornus sericea L.) in relation to freeze-tolerance. Plant Cell Physiol. 44: 25-34.

Lennartsson, M. and E. Ogren. 2002. Causes of variation in cold hardiness among fast-growing willows (Salix spp.) with particular reference to their inherent rates of cold hardening. Plant Cell Environ. 25:1279-1288.

Lim, C.C., S.L. Krebs, and R. Arora. 1999. A $25-\mathrm{kDa}$ dehydrin associated with genotypeand age-dependent leaf freezing-tolerance in Rhododendron: A genetic marker for cold hardiness? Theor. Appl. Genet. 99:912-920.

Manly, B.F.J. 1997. Randomization, bootstrap and Monte Carlo methods in biology. 2nd Ed. Chapman and Hall, London, UK.

Murray, G. and W.R. Byrnes. 1975. Effect of night temperature on dehardening in black walnut seedlings. For. Sci. 21:313-317.

Phillippe, L.R., W.C. Handel, S.L. Horn, F.M. Harty, and J.E. Ebinger. 2003. Vascular flora of Momence wetlands, Kankakee County, Illinois. Trans. Ill. State Acad. Sci. 96:271-294.
Powell, A., D. Himelrick, W. Dozier, and D. Williams. 1999. Fruit culture in Alabama: Winter chilling requirements. Alabama Coop. Ext. System ANR-53-D.

R Development Core Team. 2009. R: A language and environment for statistical computing. $\mathrm{R}$ Foundation for Statistical Computing, Vienna, Austria. 3 Aug. 2009. <http://www.R-project.org>

Rowland, L.J., E.L. Ogden, M.K. Ehlenfeldt, and B. Vinyard. 2005. Deacclimation kinetics, and bud development among 12 diverse blueberry genotypes under field conditions. J. Amer. Soc. Hort. Sci. 130:508-514.

Schrader, J.A. and W.R. Graves. 2003. Phenology and depth of cold acclimation in the three subspecies of Alnus maritima. J. Amer. Soc. Hort. Sci. 128:330-336.

Sharma, J. and W.R. Graves. 2004. Midwinter cold hardiness of Leitneria floridana from three provenances. J. Environ. Hort. 22:88-92.

Taulavuori, K.M.J., E.B. Taulavuori, O. Skre, J. Nilsen, B. Igeland, and K.M. Laine. 2004. Dehardening of mountain birch ecotypes at elevated winter temperatures. New Phytol. 162: 427-436.

The Weather Channel. 2009. Oct. 2009. <http:// www.weather.com>.

US National Arboretum. 2003. Web version of the USDA plant hardiness zone map. <http://www. usna.usda.gov/Hardzone/ushzmap.html>.

Wolf, T.K. and M.K. Cook. 1992. Seasonal deacclimation patterns of three grape cultivars at constant warm temperature. Amer. J. Enol. Viticult. 43:171-179.

Zimmerman, E.M., L.G. Jull, and A.M. Shirazi. 2005. Effects of salinity and freezing on Acer platanoides, Tilia cordata, and Viburnum lantana. J. Environ. Hort. 23:138-144. 